\title{
超高強度コンクリート充填鋼管柱の終局曲げ耐力に関する研究 ULTIMATE BENDING STRENGTH OF HIGH-STRENGTH CONCRETE FILLED STEEL TUBE COLUMN
}

\author{
最相元雄*, 安部貴之**, 中矢浩二** \\ Motoo SAISHO, Takayuki ABE and Kouji NAKAYA
}

\begin{abstract}
On the basis of stub-column test of concrete filled steel tube(CFT) and calculation of steel tube stress, the equation of confined concrete strength of CFT column is derived. This equation is a simple function expressed only by the strength ratio of steel tube to filled concrete. By the use of the equation of confined concrete strength the method to predict the ultimate bending strength of CFT column is proposed. The proposed method is the generalized superposed strength method in which the concrete strength is defined by the confined concrete strength and the steel tube strength is decided according to the calculated stress distribution. This method can predict well the maximum bending strength of CFT column test even if CFT column is the super-high strength concrete filled steel tube.
\end{abstract}

Keywords: concrete-filled steel tube, beam-column, high-strength concrete, ultimate strength, confined concrete コンクリート充填銅管、柱、高強度コンクリート、終局耐力、コンクリート拘束効果

1. 序

コンクリート立填鋼管 (CFT) はコンクリートと鋼管の長所と短所 を巧みに組み合わせた部材で、そのせん断曲げ柱は優れた耐力と塑 性変形能力を発揮することが知られている。また、その終局曲げ酎 力は累加強度式で比較的簡単に、しかも、安全側の值が計算できる ことでひろく使われている。一方、コンクリート混和材及び混和剤 の研究開発により現在では $1000 \mathrm{kgf} / \mathrm{cm}^{2}$ を越える圧縮強度の超高強 度コンクリートが比較的容易に打設可能となり、その実用化が期待 される 1)-3), 26)-29)。

著者らは超高強度コンクリートの実用化に適切な構造部材として CFT 部材を考え、超高強度コンク.リート充填鋼管せん断曲げ柱の動 載荷実験を実施し、耐震構造部材としての終局状態を明らかにする とともに、終局曲け耐力、累積塑性変形能力等の基本的性能を求め た 26)-29)。その結果によると、超高強度コンクリート充填鋼管せん 断曲げ柱の復元力特性の形状は普通強度コンクリート充填鋼管の場 合とよく似た良好な形状となり、しかも、優れた耐力と塑性変形能 力が期待できることが示された。しかし、その終局曲げ耐力の值に 注目すると、鋼管と充填コンクリートの条件によってコンクリート 拘束効果が異なるため、これによって実験值と一般化累加強度との
対㐫に顕著な差が見られ、超高強度コンクリート充填鋼管柱の終局 曲げ耐力は普通強度コンクリート充填鋼管柱の場合と同一の一般化 累加強度式では扱えないことが示された。

コンクリート拘束効果を考慮した CFT 柱の終局曲げ耐力式は既に

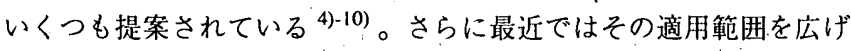
るための研究も進められており、終局曲げ耐力を支配するコンクリ 一ト圧縮強度、鋼管強度、鋼管径厚比等に関し、幅広く適用できる 終局曲げ耐力式も示されている。しかしながら、超高強度コンクリ 一ト充填鋼管柱に関しては、実験資料が少なくその終局曲げ耐力式 はほとんど検討されていない。また、耐震構造部材としてのCFT 柱 では、その終局曲け酎力は載荷速度の影響を受けるがこれについて も考慮されていない。

本論では普通強度コンクリート充填鋼管柱から超高強度コンクリ 一ト充填鋼管柱まで幅広く適用できる終局曲げ耐力式を求めるとと もに、耐震構造部材としての CFT 柱が受ける載荷速度効果と終局曲 げ耐力式との関連について述べる。なおここで鋼管は冷間成形円 形鋼管を表す。
* 能本大学 教授 $\cdot$ 工博

** 熊本大学 大学院生.
Prof., Kumamoto Univ., Dr. Eng.

Graduate Student, Kumamoto Univ. 


\section{CFT 短柱圧縮試験 \\ 2.1 試験体}

鋼管と充填コンクリートの条件によって異なるコンクリート拘束 効果を明らかにすることを目的とし、普通強度コンクリートから超 高強度コンクリートまでコンクリート圧縮強度の異なる CFT 短柱 圧縮試験を実施した ${ }^{30)}$ 。

試験体は鋼管の材料と径厚比および充填コンクリート圧縮強度を 実験変数とする合計 29 体で、これを表 1 に示す。試験体長さは全 て鋼管外径の 3 倍である。試験体の充填コンクリートは超高強度コ ンクリート、高強度コンクリート及び普通強度コンクリートの 3 種 類で、そのコンクリート圧縮強度 $\left(\sigma_{\mathrm{c}}\right)$ は超高強度コンクリートで $\sigma_{\mathrm{c}}=1250 \mathrm{kgf} / \mathrm{cm}^{2}$ 、高強度コンクリートで $\sigma_{\mathrm{c}}=500 \mathrm{kgf} / \mathrm{cm}^{2}$ 、普通強度 コンクリートで $\sigma_{\mathrm{c}}=250 \mathrm{kgf} / \mathrm{cm}^{2}$ 目標として各々調合したもので、 その調合と各試験体のコンクリート圧縮試験結果を表 2 と表 1 に示 す。コンクリート材料試験には封縅養生した材料試験体を用いた。 鋼管は冷間成形の円形鋼管で、材料は STK400, STK490 の 2 種類で ある。鋼管断面は $\phi-101.6 \times 3.2$ (STK400), $\phi-139.8 \times 2.8$ (STK400),

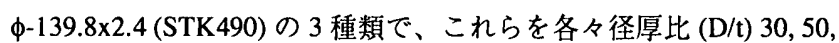
60 の鋼管と呼ぶことにする。これらの鋼管の引張試験および短柱圧 縮試験結果によって求めた材料の機械的性質を表 3 に示す。引張試 験には鋼管から切り出したJIS12 号試験片を用い、圧縮試験には柱 長さが鋼管外径の 3 倍の鋼管短柱を用いた。表 3 中の降伏応力度 $\left(\sigma_{y}, c \sigma_{y}\right)$ は $0.2 \%$ offset 值である。

\section{2 試験方法}

圧縮試験の載荷方法と測定方法を図 1 に示す。単純圧縮荷重とな るように、試験体下端には球座を設けて予測される最大荷重の約 $1 / 10$ まで載荷した後、この球座の回転を固定することで試験体不整 から生じる曲げ荷重を取り除くこととした。また、試験体端面の不 整を取り除くため、端面を研磨した後載荷した。荷重は油圧試験機 で与えたが、載荷速度の影響をできるだけ小さくするため、軸方向 平均歪速度が $50 \mu-200 \mu$ 分の範囲で定速載荷となるように制御しな がら載荷した。測定は、荷重 $(\mathrm{P})$ を油圧試験機の荷重計で、また、 試験体中央断面の鋼管表面軸方向歪と周方向歪を 2 方向歪ゲージ (WSG) で測定した。WSGの位置はシームの位置を除く管周四等分 点上である。他に載荷速度制御のため試験体の軸方向縮みを変位計 で測定した。

\section{3 実験結果}

荷重 $(\mathrm{P})$ の最大值 $\left(\mathrm{P}_{\mathrm{m}}\right)$ を表 1 にまとめて示す。普通強度コンクリ 一ト及び高強度コンクリート充填鋼管短柱では、 $\mathrm{P}_{\mathrm{m}}$ は単純累加の

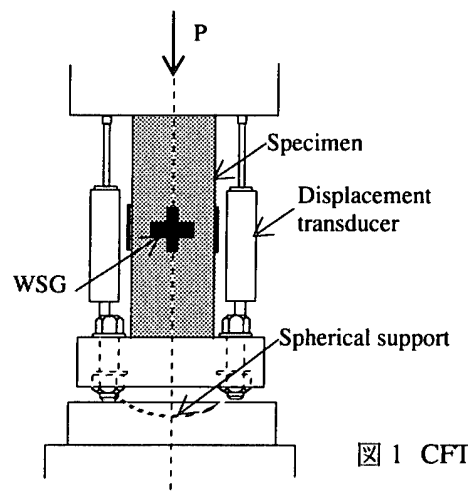

降伏圧縮強度 $\mathrm{P}_{\mathrm{y}}\left(=\sigma_{\mathrm{c}} \mathrm{A}_{\mathrm{c}}+\sigma_{\mathrm{y}} \mathrm{A}_{\mathrm{s}}, \mathrm{A}_{\mathrm{c}}\right.$ : 充填コンクリート断面積, $\mathrm{A}_{\mathrm{s}}$ : 鋼 管断面積)を越えているのに対して、超高強度コンクリート充填龬 管短柱では 2 体を除いていずれも $\mathrm{P}$ 㒓していない。これは CFT 短柱耐力に鋼管とコンクリートの相互作用が関わることを示すもの で、以下ではこの挙動における鋼管応力状態に注目して、これが支 配するコンクリート拘束効果を求める。

表 1 CFT 短柱圧縮試験体と実験結果

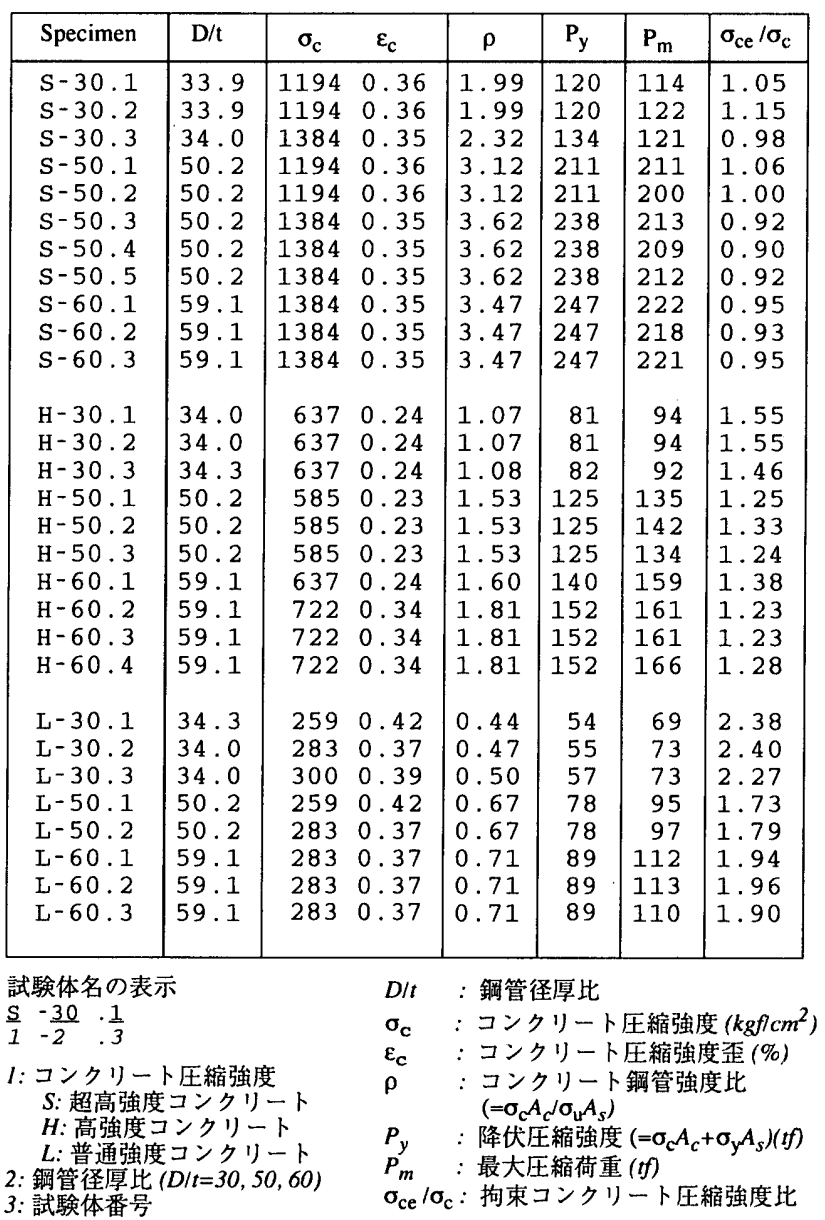

表 2 充填コンクリートの調合 (絶乾比重)

\begin{tabular}{|c|c|c|c|c|c|c|r|}
\hline \multirow{2}{*}{ コンクリート } & \multirow{2}{*}{$\mathrm{W}^{(\%)}$} & \multicolumn{6}{|c|}{ 重量割合 $\left(\mathrm{kgg} / \mathrm{m}^{3}\right)$} \\
\cline { 5 - 8 } & $\mathrm{C}+\mathrm{SF}$ & $\mathrm{W}$ & $\mathrm{C}$ & $\mathrm{SF}$ & $\mathrm{FA}$ & $\mathrm{CA}$ & $\mathrm{AD}$ \\
\hline 超高強度コンクリート & 20 & 150 & 625 & 125 & 568 & 1010 & 22 \\
高強度コンクリート & 35 & 194 & 555 & - & 591 & 1087 & 5 \\
普通強度コンクリート & 60 & 216 & 360 & - & 762 & 1063 & - \\
\hline
\end{tabular}

W: 水, C: セメント, SF: シリカフユーム,FA: 細骨材, CA: 粗骨材, AD: 混和鼡

表 3 鋼管の機械的性質

\begin{tabular}{|c|c|c|c|c|c|c|}
\hline \multirow[b]{2}{*}{ 円形銅管 } & \multicolumn{3}{|c|}{ 引張試験 } & \multicolumn{3}{|c|}{ 短柱圧縮試験 } \\
\hline & $\sigma_{\mathrm{y}}$ & $\sigma_{u}$ & $\varepsilon_{\mathrm{u}}$ & ${ }_{c} \sigma_{y}$ & ${ }_{c} \sigma_{\mathfrak{u}}$ & $c^{\varepsilon_{u}}$ \\
\hline $\begin{array}{l}\phi-101.6 \times 3.2 \\
\phi-139.8 \times 2.8 \\
\phi-139.8 \times 2.4\end{array}$ & $\begin{array}{l}3.85 \\
3.48 \\
4.72\end{array}$ & $\begin{array}{l}4.64 \\
4.52 \\
5.60\end{array}$ & $\begin{array}{l}23.8 \\
28.8 \\
22.6\end{array}$ & $\begin{array}{l}3.77 \\
3.34 \\
4.38\end{array}$ & $\begin{array}{l}4.27 \\
3.60 \\
4.74\end{array}$ & $\begin{array}{l}2.05 \\
0.86 \\
0.79\end{array}$ \\
\hline
\end{tabular}

$\sigma_{\mathrm{y}}:$ 引張降伏応力度 $\left(\mathrm{t} f / \mathrm{cm}^{2}\right)$ $\sigma_{\mathrm{u}}:$ 引張強さ $\left(\mathrm{t} f / \mathrm{cm}^{2}\right)$ $\varepsilon_{\mathrm{u}}:$ 一様伸び $(\%)$ $c \sigma_{\mathrm{y}}$ : 压縮降伏応力度 $\left(\mathrm{t} f / \mathrm{cm}^{2}\right)$ ${ }_{c} \sigma_{\mathrm{u}}$ : 最大压縮応力度 $\left(\mathrm{t} / \mathrm{cm}^{2}\right)$ $\mathfrak{c}^{\varepsilon_{u}}$ : 最大压縮応力時の圧縮䄳 (\%) 


\section{CFT 短柱の圧縮挙動}

\section{1 鋼管歪と鋼管応力度}

各試験体の鋼管表面昰を充填コンクリートと鋼管の違いに関係な く同じ座標上に表したものを図 2 に示す。各值は鋼管表面に貼った 4 枚の雨ゲージの平均值である。横軸は軸方向雨 $\left(\varepsilon_{\mathrm{A}}\right)$ で、縦軸に周 方向歪 $\left(\varepsilon_{\mathrm{T}}\right)$ を表した場合を○印で、また、周方向と軸方向の歪増分比 $\left(\Delta \varepsilon_{\mathrm{T}} / \Delta \varepsilon_{\mathrm{A}}\right)$ の值を表した場合を○印で示す。

鋼管歪は $\varepsilon_{\mathrm{A}}=-\varepsilon_{\mathrm{y}}\left(\varepsilon_{\mathrm{y}}\right.$ : 引張降伏歪 $)$ に至るまでは弾性的に挙動し、 $\varepsilon_{\mathrm{A}}$ が降伏点に達した後には、 $\varepsilon_{\mathrm{A}}-\varepsilon_{\mathrm{T}}$ 関係は勾配を変えていずれも直 線的となっている。鋼管降伏後に歪増分比 $\Delta \varepsilon_{\mathrm{T}} / \Delta \varepsilon_{\mathrm{A}}$ 值がほほ一定值 となる挙動は、これまでの実験結果に共通して認められる挙動で既

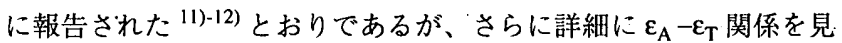
ると次のとおりである。即ち、いずれの試験体も鋼管が降伏すると $\left|\Delta \varepsilon_{\mathrm{T}} / \Delta \varepsilon_{\mathrm{A}}\right|$ 值が急堌し、その後も $\left|\Delta \varepsilon_{\mathrm{T}} / \Delta \varepsilon_{\mathrm{A}}\right|$ 值は徐々に增加を続け、 $\Delta \varepsilon_{\mathrm{T}}=-\Delta \varepsilon_{\mathrm{A}}$ の状態にまで達するか、あるいは、 $\Delta \varepsilon_{\mathrm{T}}=-\Delta \varepsilon_{\mathrm{A}}$ の状態に 達しない場合も軸方向圧縮歪の増加とともにこの状態に漸近してい 方。

次にMises の降伏条件にようて鋼管応力度を求める。鋼管の歪硬 化後の降伏条件を Mises の降伏条件式で (1) 式のように表すことに する。

$$
\sigma_{\mathrm{A}}^{2}-\sigma_{\mathrm{A}} \sigma_{\mathrm{T}}+\sigma_{\mathrm{T}}^{2}=\sigma_{\mathrm{u}}^{2}
$$

ここで $\sigma_{\mathrm{A}}, \sigma_{\mathrm{T}}$ は鋼管の軸方向応力度と周方向応力度で、 $\sigma_{\mathrm{u}}$ は鋼 管の引張強さである。冷間成形鋼管の応力度歪関係はラウンド八ウ

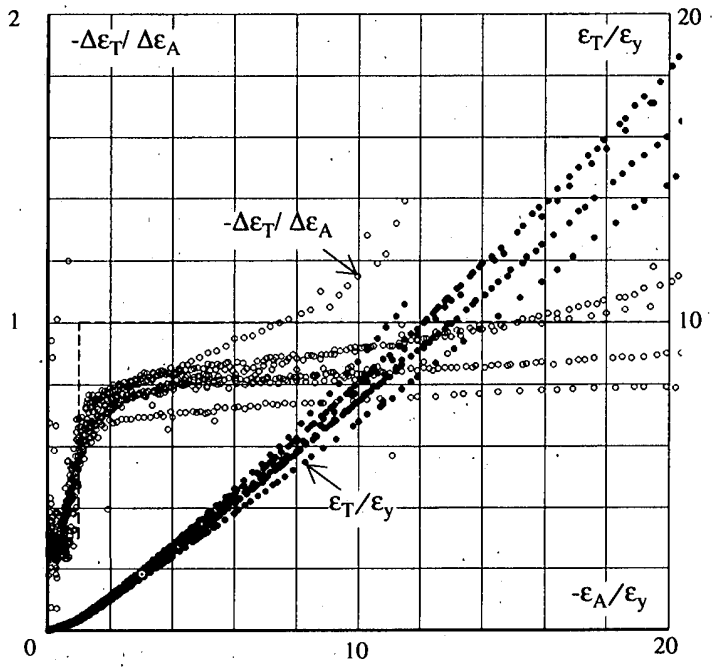

図 2 鋼管軸方向歪と周方向歪及び歪増分比の関係

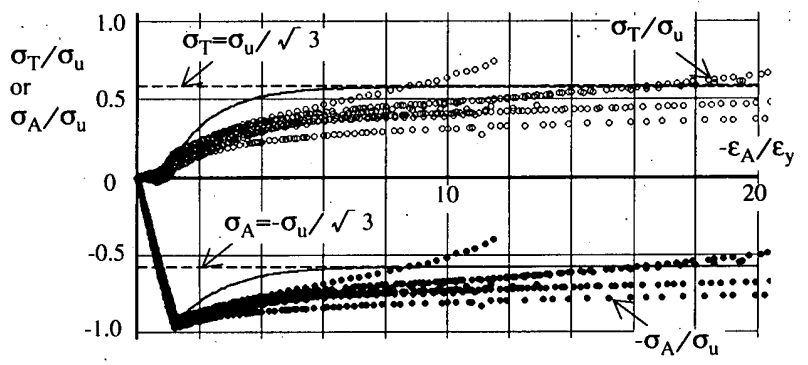

図 3 鋼管軸方向歪と軸方向及び周方向応力度の関係
ス型で降伏直後からの歪硬化が顕著であり、応力度歪関係は塑性域

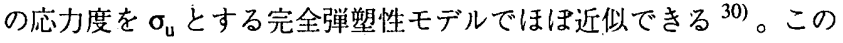
理由によって、ここでは降伏条件式を鋼管引張強さ $\left(\sigma_{\mathrm{u}}\right)$ で定義す る。この場合の鋼管軸方向応力度增分 $\left(\Delta \sigma_{\mathrm{A}}\right)$ と周方向応力度增分 $\left(\Delta \sigma_{\mathrm{T}}\right)$ に関する構成方程式は、(1) 式の降伏条件を塑性ポテンシャル として次式のように表される。

$\{\Delta \sigma\}=\left[D^{\mathrm{P}}\right]\{\Delta \varepsilon\}$

但し、 $\{\Delta \sigma\}=\left[\Delta \sigma_{\mathrm{A}} \Delta \sigma_{\mathrm{T}}\right]^{\mathrm{T}},\{\Delta \varepsilon\}=\left[\Delta \varepsilon_{\mathrm{A}} \Delta \varepsilon_{\mathrm{T}}\right]^{\mathrm{T}},\left[\mathrm{D}^{\mathrm{P}}\right]$ : 弾塑性剛性行列 である。また、歪硬化後の状態を考えているため、(2) 式に歪硬化 成分は含まれてない。

(2) 式によると、 $\sigma_{\mathrm{A}}=-\sigma_{\mathrm{u}} / \sqrt{ } 3, \sigma_{\mathrm{T}}=\sigma_{\mathrm{u}} / \sqrt{ } 3$ の状態に $\Delta \varepsilon_{\mathrm{T}}=-\Delta \varepsilon_{\mathrm{A}}$ の 条件を与えると (3) 式となる。

$\{\Delta \sigma\}=\{0\}$

いま、歪増分比 $\Delta \varepsilon_{\mathrm{T}} / \Delta \varepsilon_{\mathrm{A}}$ 值が図 2 の破線で表される場合、即ち、 $-1<\varepsilon_{\mathrm{A}} / \varepsilon_{\mathrm{y}}<0$ の範囲で $\Delta \varepsilon_{\mathrm{T}} / \Delta \varepsilon_{\mathrm{A}}=-v\left(=-0.3, v:\right.$ ポアソン比)、 $\varepsilon_{\mathrm{A}} / \varepsilon_{\mathrm{y}}<-1$ の 範囲で $\Delta \varepsilon_{\mathrm{T}} / \Delta \varepsilon_{\mathrm{A}}=-1.0$ となる場合の鋼管応力度 $\left(\sigma_{\mathrm{A}}, \sigma_{\mathrm{T}}\right)$ を(2) 式によ って求めると、(4) 式の値に達した後 (3) 式の条件によってこの点に 停留する。

$$
\sigma_{\mathrm{A}}=-\sigma_{\mathrm{u}} / \sqrt{ } 3, \quad \sigma_{\mathrm{T}}=\sigma_{\mathrm{u}} / \sqrt{ } 3 .
$$

この状態を表したのが図 3 の実線である。図 3 は鋼管軸方向歪 $\left(\varepsilon_{\mathrm{A}}\right)$ に対する鋼管応力度 $\left(\sigma_{\mathrm{A}}, \sigma_{\mathrm{T}}\right)$ の変化を表したもので、この図に は実験值の鋼管歪 $\left(\varepsilon_{\mathrm{A}}, \varepsilon_{\mathrm{T}}\right)$ (図 2) に対する鋼管応力度 $\left(\sigma_{\mathrm{A}}, \sigma_{\mathrm{T}}\right)$ を (2) 式によって計算した値もの印と○印で示している。その結果は、い ずれの試験体においても鋼管圧縮昰が増加すると実線と同じく $\sigma_{\mathrm{A}}$, $\sigma_{\mathrm{T}}$ は (4) 式の值に達するか、あるいはこの值に漸近する結果となっ ている。即ち、鋼管の軸方向塑性歪が充分大きくなると鋼管応力度は (4) 式の值で近似できることを示している。

\section{2 拘束コンクリート圧縮強度 $\left(\sigma_{\mathrm{ce}}\right)$}

鋼管応力度を(4) 式で近似して、鋼管から拘束を受けるコンクリ 一下圧縮強度 (以後、拘束コンクリート圧縮強度と呼ぶ)を求め る。拘束コンクリート圧縮強度は CFT 短柱が最大荷重に達した時の コンクリート応力度とし、この值を CFT 短柱の最大荷重 $\left(\mathrm{P}_{\mathrm{m}}\right)$ から 鋼管応力を差し引くことにより(5) 式で求める。

$$
\sigma_{\mathrm{ce}}=\left\{\mathrm{P}_{\mathrm{m}}-\left(\sigma_{\mathrm{u}} / \sqrt{ } 3\right) \mathrm{A}_{\mathrm{s}}\right\} / \mathrm{A}_{\mathrm{c}}
$$

但し、充填コンクリートと鋼管の関係によっては、鋼管応力度が (4) 式の值に達する以前にCFT 短柱の圧縮荷重が最大荷重となる場 合がある ${ }^{30)}$ 。この場合 $\sigma_{\mathrm{ce}}$ は実際の拘束コンクリート压縮強度を表 さずこれに相当する值となるが、ここではこれを拘束コンクリート 王縮強度と呼ぶこととする。各短柱圧縮試験体について、拘束コン クリート圧縮強度 $\left(\sigma_{\mathrm{ce}}\right)$ と材料試験のコンクリート压縮強度 $\left(\sigma_{\mathrm{c}}\right)$ と の比を求めて図 4 に示す。図の横軸は銅管と充填コンクリートの強 度比 $1 / \rho\left(=\sigma_{\mathrm{u}} \mathrm{A}_{\mathrm{s}} / \sigma_{\mathrm{c}} \mathrm{A}_{\mathrm{c}}\right)$ である。実験值はほほ直線分布し、図中に破 線で示す (6) 式で良好に近似できる。

$$
\sigma_{\mathrm{ce}} / \sigma_{\mathrm{c}}=0.76 / \rho+0.76
$$

但し $\rho=\sigma_{\mathrm{c}} \mathrm{A}_{\mathrm{c}} / \sigma_{\mathrm{u}} \mathrm{A}_{\mathrm{s}}$ で $\rho \neq 0$ とする。図 5 も同じ $\sigma_{\mathrm{ce}} / \sigma_{\mathrm{c}}$ を表したも ので、図 4 の值 (O印) の他に既報の CFT 短柱圧縮試験の試験結果 13)-23) を○印で示す。引用したのは本論と同じ載荷条件で実施され た冷間成形円形鋼管の CFT 短柱圧縮試験で、鋼管の引張強さ $\left(\sigma_{\mathrm{u}}\right)$ 
が明示されている合計 85 体の試験結果である。各試験体のコンク リート压樎強度 $\left(\sigma_{\mathrm{c}}\right)$ は $176 \mathrm{kgf} / \mathrm{cm}^{2}<\sigma_{\mathrm{c}}<1842 \mathrm{kgf} / \mathrm{cm}^{2}$ 、鋼管降伏応力 度 $\left(\sigma_{\mathrm{y}}\right)$ は $2.84 \mathrm{tf} / \mathrm{cm}^{2}<\sigma_{\mathrm{y}}<8.51 \mathrm{tf} / \mathrm{cm}^{2}$ 、鋼管外径 (D) は $101.6 \mathrm{~mm}<\mathrm{D}<450.0 \mathrm{~mm}$ 、鋼管径厚比 $(\mathrm{D} / \mathrm{t})$ は $16.7<\mathrm{D} / \mathrm{t}<152.0$ で、その 試験範囲は極めて幅広い。これに対して図 5 に示す結果はほほ直線 分布しており、(6) 式の妥当性とともにこの直線関係が幅広いCFT 短柱においても成立することが示されている。

なお、CFT 短柱の拘束効果によるコンクリートの強度上昇は、拘 束係数 $(K)$ と充填コンクリート表面に作用する拘束応力度 $\left(\sigma_{\mathrm{r}}\right)$ との 積 $\left(K \sigma_{\mathrm{r}}\right)$ で表される場合が多く 1), 5), 11), 24)-25) 、その拘束応力度と鋼 管応力度は Mises の降伏条件に従って求められている。この手法は 一般に CFT 短柱の最大圧縮荷重 $\left(\mathrm{P}_{\mathrm{m}}\right)$ が $\mathrm{P}_{\mathrm{y}}\left(=\sigma_{\mathrm{c}} \mathrm{A}_{\mathrm{c}}+\sigma_{\mathrm{y}} \mathrm{A}_{\mathrm{s}}\right)$ を上回る場 合を対象とするもので、 $\mathbf{P}_{\mathrm{m}}<\mathrm{P}_{\mathrm{y}}$ の場合、即ち、鋼管径厚比が大き い場合 ${ }^{18)}$ や超高強度コンクリートを充填した場合 ${ }^{30)}$ の CFT 短柱で は条件によって最大圧縮荷重が $\mathrm{P}_{\mathrm{y}}$ 以下になるが、これらに対して この手法は適用できない。これと異なり(6) 式は $\mathrm{P}_{\mathrm{m}}<\mathrm{P}_{\mathrm{y}}$ の場合も 適用可能な近似式である。

\section{$4 \mathrm{CFT}$ 柱の終局曲げ耐力実験}

CFT 柱の終局曲げ耐力式を導き、且つ、その終局曲げ耐力式の妥 当性を検討するために、既に報告した CFT せん断曲げ柱の実験結果 26)-29) を用いる。その実験概要は以下のとおりである。CFT せん断 曲げ柱実験は多層剛節骨組の柱部材を想定し、一定軸力と繰り返し

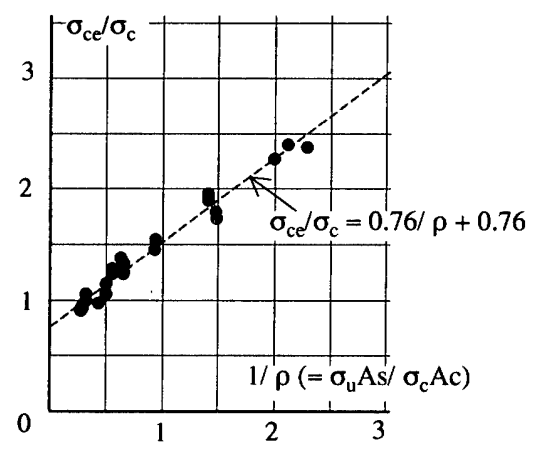

図 4 拘束コンクリート圧縮強度の実験值と近似式

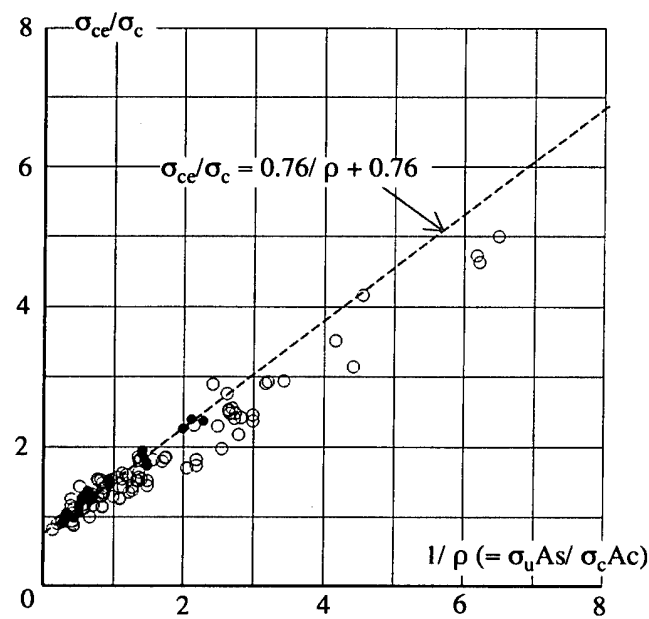

図 5 既報 ${ }^{13)-23)}$ の実験值と拘束コンクリート圧縮強度近似式との比較

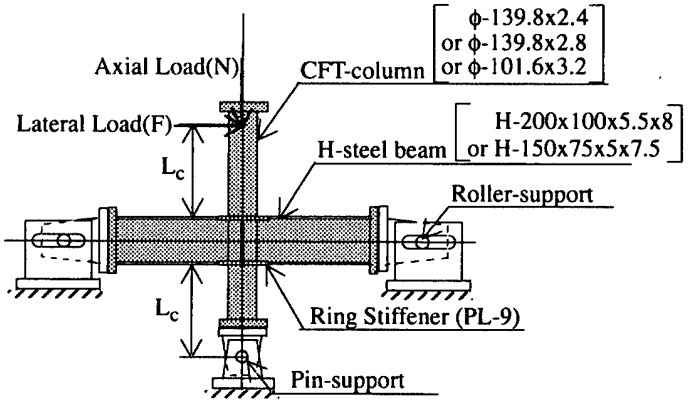

図 6 CFT 柱試験体

せん断曲げ荷重を受ける部材が実験対象である。柱の終局曲げ耐力 は柱端の条件、即ち、柱はり接合部の条件によって影響をうけるた め、試験体は図 6 のような円形鋼管の CFT 柱と $\mathrm{H}$ 形鋼はりで構成 される十字型試験体である。試験対象は CFT 柱部分であるため、H 形鋼はりおよび接合部のリングスチフナーには充分な強度を与え て、試験終了まで弾性範囲におさまるように設計した。鋼管柱の両 端にはエンドプレートを溶接し、鋼管と充填コンクリートの間のず れに対してはこのエンドプレートで拘束する。CFT 柱部材の終局曲 け耐力と終局状態に関わる変数として、鋼管の材料と径厚比、充填 コンクリート圧縮強度、柱軸力比、柱長さ、載荷速度、載荷履歴を 想定し、これらを実験変数とする合計 70 体の試験体について実験 した。各試験体の試験条件を表 4 に示す。充填コンクリートは 2 節 の短柱試験体と同じ調合で、その圧縮強度は表 4 に示すとおりであ る。また、鋼管も前述の短柱圧縮試験と同じ鋼管を用いた。試験体 の荷重条件と支持条件は図 7 に示すように、柱端がピン支持、はり 両端がローラ一支持という支持条件で、柱他端に一定軸力 $(\mathrm{N})$ と横 力 (F) を作用させるものである。載荷速度が終局曲げ耐力に及ほす 影響を知る目的で、横力を動載荷する実験と静載荷する実験を実施 した。実験結果の例を図 8 と図 9 に示す。図は柱脚に作用する曲げ 荷重 $\mathrm{M}_{\mathrm{c}}\left(=\mathrm{N} \delta_{\mathrm{c}}+\mathrm{F} \mathrm{L}_{\mathrm{c}}\right)$ と柱変形角 $\left(\delta_{\mathrm{c}} / \mathrm{L}_{\mathrm{c}}\right)$ で表した荷重変形関係で、図 中、矢印は鋼管局部座屈発生点 $(L B)$ 、最大曲げ荷重点 $\left(M_{m}\right)$ 及び終 局状態の鋼管亀裂発生点 (Crack) を表す。これらの図に見られるよ うに、本実験では鋼管局部座屈は柱変形角の振幅が $\delta_{\mathrm{c}} / L_{\mathrm{c}}=1 / 30-1 / 20$ の範囲で発生しているが、これによる顕著な酎力劣化は認められ ず、鋼管局部座屈が最大曲げ荷重を直接支配していない。図 8 は普 通強度コンクリートから超高強度コンクリートまで充填コンクリー 卜圧縮強度が互いに異なる場合の実験結果で、図 9 は動載荷実験値 と静載荷実験值の比較であるが、最大曲げ荷重点 $\left(\mathrm{M}_{\mathrm{m}}\right)$ までに注目 する限り、いずれもその復元力特性は互いによく似た形状となるこ とがわかる。そこで、荷重の向き及び変位履歴上の位置に関係なく 荷重の最大值 $\left(\mathrm{M}_{\mathrm{m}}\right)$ を求め、この值をまとめて表 4 に示す。なお、 一定軸力と繰り返し横力を受ける CFT 柱では、一定軸力保持不能と

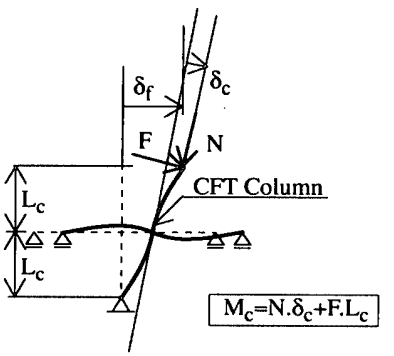

図 7 試験条件 （荷重条件と支持条件） 

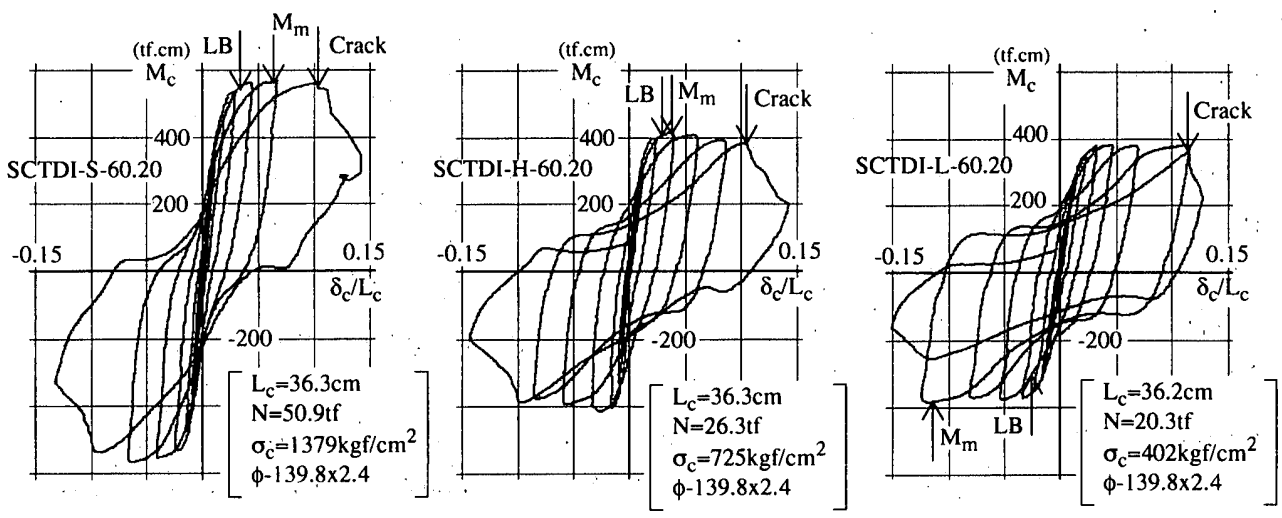

図 8 荷重変形関係(コンクリート強度が異なる場合)

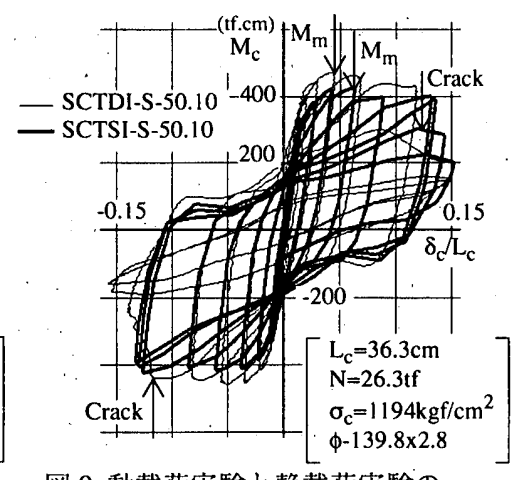

図 9 動載荷実験と静載荷実験の 荷重変形関係
なり終局状態になる場合と鋼管に亀裂が発生し終局状態となる場合 がある ${ }^{29)}$ 。前者は試験終了まで曲げ耐力が上昇を続けて最大曲げ荷 重が得られないため、ここでは後者の試験結果のみを表 4 に示す。 但し、コンクリートを充填しない試験体については最大曲げ荷重が 読み取れるためこれらを含める。

\section{5 繰り返し荷重を受ける CFT 柱の鋼管昰と鋼管応力度}

CFT 柱が繰り返し荷重を受ける場合、その曲げ压縮断面の挙動と CFT 短柱圧縮挙動がいかに対応するかは明確でないため、ここでは CFT 柱の実験で得られた鋼管の歪を使って両者の関係を検討し、終 局曲げ耐力時の鋼管の応力状態とコンクリート拘束効果を求める。

$\mathrm{CFT}$ 柱の鋼管表面軸方向歪 $\left(\varepsilon_{\mathrm{A}}\right)$ と周方向歪 $\left(\varepsilon_{\mathrm{T}}\right)$ の関係を図 10 に 示す。この歪は柱脚から $30 \mathrm{~mm}$ ( 但し鋼管径厚比 $\mathrm{D} / \mathrm{t}=50$ の場合) の 鋼管表面に貼った 2 方向歪ゲージ (WSG1, WSG2) から求めた值で、
図中の太線と細線は荷重面内の鋼管両側の歪を表す。この歪ゲージ 位置には鋼管局部座屈が発生するが、図の歪は局部座屈発生前まで の值である。図中の破線は CFT 短柱圧縮試験の歪增分関係 (図 2) に破線で示した場合の值であるが、せん断曲げ荷重を受ける CFT 柱 においても同様な挙動が見られる。即ち、せん断曲げ荷重が繰り返 し作用する場合も、繰り返し数と塑性歪振幅に関係なく、軸方向圧 縮歪が増加すると $\left(\Delta \varepsilon_{\mathrm{A}}<0\right) 、\left|\Delta \varepsilon_{\mathrm{T}} / \Delta \varepsilon_{\mathrm{A}}\right|$ 值は徐々に増加を絗け、やが て、 $\Delta \varepsilon_{\mathrm{T}} \doteq-\Delta \varepsilon_{\mathrm{A}}$ の関係が現われ、ほほその状態が継続している。あ るいは、この状態に達していない場合も、この状態に $\varepsilon_{\mathrm{A}^{-}} \varepsilon_{\mathrm{T}}$ 関係は 漸近している。この性状はコンクリート鋼管強度比 $(\rho)$ が異なるい ずれの試験体にも共通して現われている。

図 $10 の \varepsilon_{\mathrm{A}}-\varepsilon_{\mathrm{T}}$ 関係に対して、鋼管軸方向応力度 $\left(\sigma_{\mathrm{A}}\right)$ と周方向応 力度 $\left(\sigma_{\mathrm{T}}\right)$ を(2) 式によって計算した結果が図 11 で、図中の○印と

○印は各々図 10 の細線 (WSG1) と太線 (WSG2) の歪に対する鋼管応
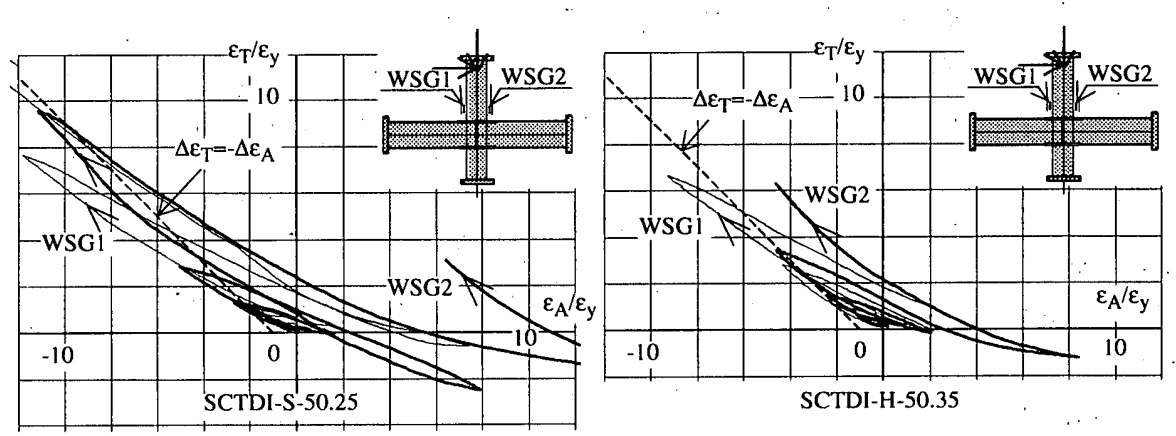

図 10 鋼管の軸方向歪と周方向歪の関係
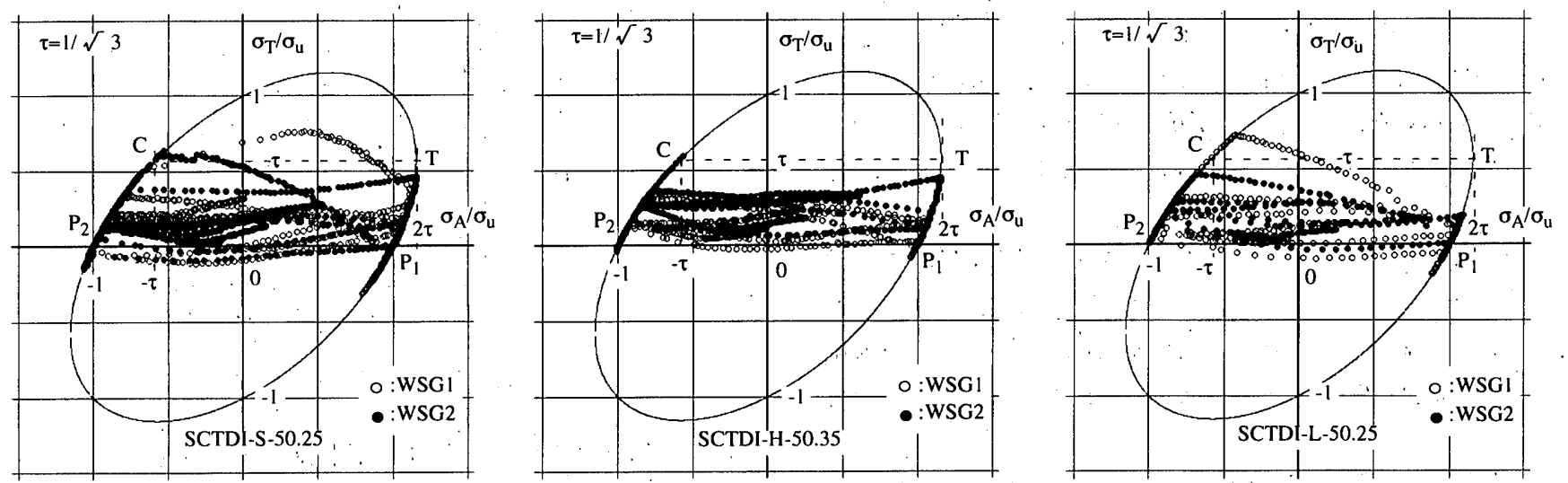

図 11 鋼管の軸方向応力度と周方向応力度の履歴

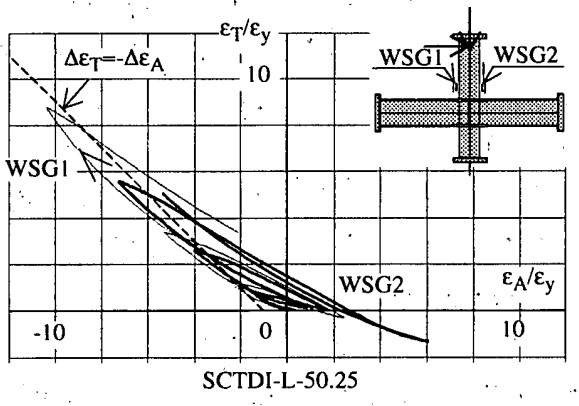

SCTDI-L-50.25 
力度を表す。実線は (1) 式の Mises の降伏条件である。図には概略 以下の性状が認められる。即ち、交番繰り返し塑性変形を受ける各 試験体では、鋼管軸方向応力度 $\left(\sigma_{\mathrm{A}}\right)$ が正負交互に降伏し、各サイク ル毎に $\mathrm{T}(2 \tau, \tau) \rightarrow \mathrm{P}_{1}(1,0) \rightarrow \mathrm{P}_{2}(-1,0) \rightarrow \mathrm{C}(-\tau, \tau)$ の履歴を描きながら $\mathrm{C}$ 点近傍と $\mathrm{T}$ 点近傍を往復する (但し $\tau=1 / \sqrt{ } 3)$ 。とくに、軸方向圧 縮歪が進み充分塑性化した状態では、鋼管応力度 $\left(\sigma_{\mathrm{A}}, \sigma_{\mathrm{T}}\right)$ は C $\left(-\sigma_{\mathrm{u}}\right)$ $\left.\sqrt{ } 3, \sigma_{\mathrm{u}} / \sqrt{ } 3\right)$ 点の近傍に停留している。これは、塑性変形が充分進 んだ状態において、繰り返し荷重を受ける CFT 柱の鋼管圧縮応力度 が、CFT 短柱圧縮試験の鋼管とほほ同じ忍力状態となることを意味 する。これらの結果に基づくと、CFT 柱の終局曲げ耐力時の応力状 態を次の応力状態で近似できる。

i) 䤡管の軸方向圧縮応力度は $\sigma_{\mathrm{u}} / \sqrt{ } 3$ で、軸方向引張応力度は $2 \sigma_{\mathrm{u}} / \sqrt{ } 3$ である。

ii) 充填コンクリートは短柱の最大圧縮荷重時と同じ拘束を受け て、拘束コンクリート圧縮強度は (6) 式の $\sigma_{\mathrm{ce}}$ 值となる。

\section{CFT 柱の終局曲げ耐力}

繰り返し荷重を受けるCFT 柱が終局曲げ耐力に達した時の応力状 態を前節の i) と ii)の条件に基づいて表し、且つ、その応力度分布 を鋼管も立填コンクリートもともに矩形分布とすると、図 12 の断 面応力状態となる。これに一般化累加強度式を適用して (7) 式の終 局曲げ酎力 $\left(\mathrm{M}_{\mathrm{ue}}\right)$ を得る。

$$
\begin{aligned}
& \mathrm{M}_{\mathrm{ue}}=\mathrm{e}_{\mathrm{c}} \mathrm{M}_{\mathrm{ue}}+_{\mathrm{s}} \mathrm{M}_{\mathrm{ue}} \\
& \mathrm{N}={ }_{\mathrm{c}} \mathrm{N}_{\mathrm{e}}+{ }_{\mathrm{s}} \mathrm{N}_{\mathrm{e}}
\end{aligned}
$$

ここで、 ${ }_{\mathrm{c}} \mathrm{M}_{\mathrm{ue}},{ }_{\mathrm{s}} \mathrm{M}_{\mathrm{ue}}$ は図 12 の全塑性応力状態における各々コンク リートと鋼管の終局曲げ耐力であり、 $\mathrm{c}_{\mathrm{c}} \mathrm{e}_{\mathrm{e}}, \mathrm{N}_{\mathrm{e}}$ は同じ応力状態での コンクリートと鋼管の軸力を各々表す。

この $\mathrm{M}_{\mathrm{ue}}$ 值と実験結果 $\left(\mathrm{M}_{\mathrm{m}}\right)$ を比較して表 4 に示す。また、同じ 結果を図 13 と図 14 にの印で示す。図の横軸はコンクリート拘束効 果を表す変数として (6) 式で導入した充填コンクリートと鋼管の強 度比 $(\rho)$ である。

図 13 と図 14 にはコンクリート圧縮強度 $\left(\sigma_{\mathrm{c}}\right)$ と鋼管降伏応力度 $\left(\sigma_{y}\right)$ でコンクリートと鋼管の耐力を表し、一般化累加強度式で計算 した終局曲げ耐力 $\left(\mathrm{M}_{\mathrm{u}}\right)$ を○印で示す。 $\mathrm{M}_{\mathrm{u}}$ 值には鋼管の歪硬化及び コンクリート拘束効果が含まれてないため、当然のことながら、こ れらが原因となって実験値との対応は良くない。その值はコンクリ 一ト銅管強度比 $(\rho)$ によって異なり、1.12 $\leqq \mathrm{M}_{\mathrm{m}} / \mathrm{M}_{\mathrm{u}} \leqq 1.94$ と幅広 い。とくに、高強度コンクリート充填鋼管柱あるいは超高強度コン クリート充填鋼管柱、即ち、コンクリート鋼管強度比 $(\rho)$ が大きい 範囲において実験值は計算值を上まわるもののその割合が小さく、 単純に一般化累加強度 $\left(\mathrm{M}_{\mathrm{u}}\right)$ を普通強度コンクリート立填鋼管柱か ら超高強度コンクリート充填鋼管柱まで一律に適用できないことが 示されている。

これに対して $\mathrm{M}_{\mathrm{ue}}$ 值は $0.95 \leqq \mathrm{M}_{\mathrm{m}} / \mathrm{M}_{\mathrm{ue}} \leqq 1.44$ で $\mathrm{M}_{\mathrm{m}} / \mathrm{M}_{\mathrm{u}}$ 值に比較 して良い結果となっている。とくに、 $\mathrm{M}_{\mathrm{m}} / \mathrm{M}_{\mathrm{ue}}$ 值は普通強度コンク リートから超高強度コンクリートまで充填するコンクリート圧縮強 度にほとんど影響を受けない結果となっており、この点で $\mathrm{M}_{\mathrm{m}} / \mathrm{M}_{\mathrm{u}}$ 值と異なる。

図 9 に示したようにCFT 柱の最大曲げ荷重は載荷速度の影響を

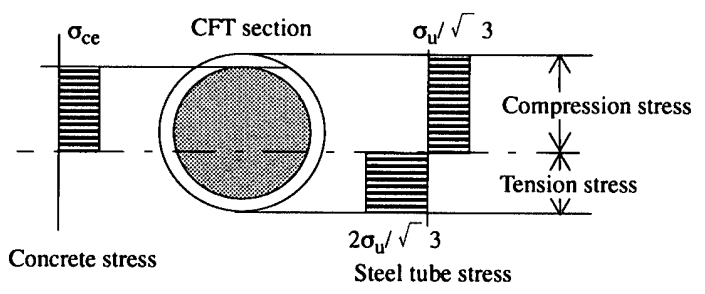

図 12 終局曲げ耐力時の CFT 断面応力状態

受ける。この載荷速度効果による最大曲げ荷重の違いを区別して示 したのが図 13 と図 14 で、前者は静載荷実験結果で後者は動載荷実 験結果である。両者を比較すると載荷速度効果によって $\mathrm{M}_{\mathrm{m}} / \mathrm{M}_{\mathrm{u}}$ 值 と $\mathrm{M}_{\mathrm{m}} / \mathbf{M}_{\mathrm{ue}}$ 值が増加する挙動が明らかに認められる。

また、CFT 柱の実験はせん断曲げ荷重を与える実験で、その最大 曲げ荷重を求めるに際しては、柱脚に作用する曲げ荷重 $\left(\mathrm{M}_{\mathrm{c}}\right)$ の最大 值を最大曲げ荷重とした。既に指摘されているように6)、柱脚では 溶接による断面増加とリングスチフナーからの拘束があって柱断面 の曲げ耐力は高くなり、柱脚からある程度離れた部材断面が限界に 達することで CFT 柱の最大曲げ荷重 $\left(\mathrm{M}_{\mathrm{m}}\right)$ が決まっている。このモ ーメント勾配の影響を求めるため、実験ではシアースパン比が約

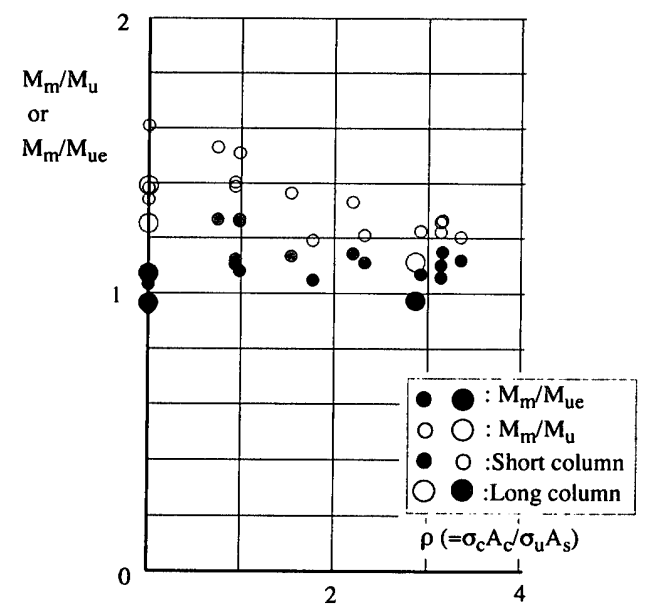

図 13 終局曲げ耐力計算值と静載荷実験値の比較

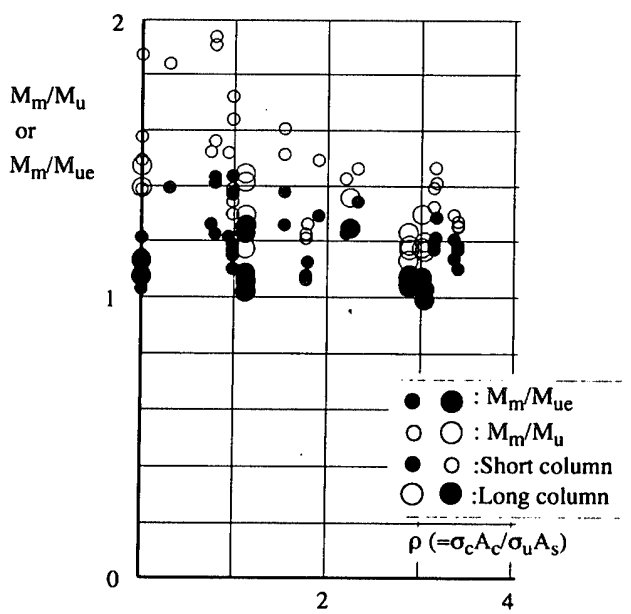

図 14 終局曲げ酎力計算値と動載荷実験値の比較 
2.5 の試験体とシアースパン比が約 5.0 の試験体を用意したが、図 13 と図 14 の結果には両者の差が明確に現われている。

結局、 $\mathbf{M}_{\mathrm{ue}}$ 式ではこの載荷速度効果とモーメン、ト勾配の影響を無 視しているため、これらが $\mathrm{M}_{\mathrm{m}}$ 值と $\mathrm{M}_{\mathrm{ue}}$ 值の差の原因となってい る。現実に剛節骨組の柱を対象とする限り載荷速度効果とモーメン 卜勾配の影響を受けることは不可避であり、これは今後の課題であ る。しかし、その影響の範囲は図 13 と図 14 に示す程度であり、 $\mathrm{M}_{\mathrm{ue}}$ 式は充分有効な終局曲げ酎力式である。

なお、コンクリートを充填しない鋼管柱 $(\rho=0)$ の $\mathrm{M}_{\mathrm{ue}}$ 計算では鋼 管断面応力度分布を引張強さ $\sigma_{\mathrm{u}}$ の矩形分布としたが、CFT 柱と同 様に良い結果となった。

\section{7 結論}

i) CFT 短柱圧縮試験の鋼管軸方向歪と周方向歪の特性に注目し、 拘束コンクリート王縮強度式を求めた。この式は鋼管コンクリート 強度比に関する直線式で、普通強度コンクリート充填鋼管短柱から 超高強度コンクリート充填鋼管短柱まで幅広いCFT 短柱に対してコ ンクリート拘束効果を表わすことができる。”。

ii) 拘束コンクリート生縮強度式を一般化累加強度式に適用し、 CFT 柱の終局曲げ耐力式を導いた。この式は普通強度コンクリート 充填鋼管柱から超高強度コンクリート充填鋼管柱まで幅広い CFT 柱 を対象とし、繰り返し荷重を受ける CFT 柱の終局曲け耐力を求める のに有効である。但し、CFT 柱の終局曲げ耐力が受ける載荷速度効 果とモーメント勾配の影響はこの式には含まれてない。

表 4.A 試験体と実験結果 ( $\$ 139.8 \times 2.4$ の試験体)

\begin{tabular}{|c|c|c|c|c|c|c|c|c|c|}
\hline Specimen & oading & $N / N_{u}$ & $\mathrm{~L}_{\mathrm{c}}$ & $\mathrm{D} / \mathrm{t}$ & $\sigma_{\mathrm{c}}$ & $\rho$ & $\mathrm{M}_{\mathrm{m}}$ & $\mathrm{M}_{\mathrm{m}} / \mathrm{M}_{\mathrm{u}}$ & $\mathrm{M}_{\mathrm{m}} / \mathrm{M}_{\mathrm{ue}}$ \\
\hline $\begin{array}{l}\text { SCTDI-S-60.20 } \\
\text { SCTDI-S -60.10 } \\
\text { SCTDI-H-60.20 } \\
\text { SCTDI-L-60.45 } \\
\text { SCTDI-L- } 50.25 \\
\text { SCTDI-L-60.20 }\end{array}$ & $\begin{array}{ll}\text { D } & \text { I } \\
\text { " } & \text { " } \\
\text { " } & \text { " } \\
\text { " } & \text { " } \\
\text { " } & \end{array}$ & $\begin{array}{l}0.199 \\
0.103 \\
0.161 \\
0.437 \\
0.226 \\
0.174\end{array}$ & & $\begin{array}{l}58.1 \\
58.1 \\
57.7 \\
57.9 \\
57.9 \\
57.9\end{array}$ & $\begin{array}{r}725 \\
402 \\
402 \\
402\end{array}$ & & & $\begin{array}{l}1.27 \\
1.25 \\
1.21 \\
1.64 \\
1.34 \\
1.30\end{array}$ & $\begin{array}{l}1.18 \\
1.10 \\
1.06 \\
1.37 \\
1.15 \\
1.10\end{array}$ \\
\hline $\begin{array}{l}\text { SCTDC-S - } 60.20 \\
\text { SCTDC-S -60.10 } \\
\text { SCTDC-H-60.20 } \\
\text { SCTDC-L-60.45 } \\
\text { SCTDC-L-60.20 } \\
\text { STDC -O-60.45 }\end{array}$ & 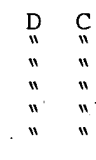 & $\begin{array}{l}0.198 \\
0.102 \\
0.161 \\
0.450 \\
0.200 \\
0.445\end{array}$ & & $\begin{array}{l}57.4 \\
57.7 \\
57.9 \\
57.9 \\
57.9\end{array}$ & $\begin{array}{r}1379 \\
1379 \\
725 \\
402 \\
402\end{array}$ & $\begin{array}{l}0.9 \\
0.9\end{array}$ & & $\begin{array}{l}1.30 \\
1.29 \\
1.23 \\
1.72 \\
1.39 \\
1.39\end{array}$ & $\begin{array}{l}1.21 \\
1.14 \\
1.08 \\
1.44 \\
1.39 \\
1.03\end{array}$ \\
\hline $\begin{array}{l}\text { SCTSC-S }-60.20 \\
\text { SCTSC-S } 60.10 \\
\text { SCTSC-H } 60.20 \\
\text { SCTSC-L-60.45 } \\
\text { SCTSC-L-60.20 }\end{array}$ & $\begin{array}{ll}\text { S } & \text { C } \\
\text { "1 } & " 1 \\
\text { " } & \text { " } \\
\text { " }\end{array}$ & $\begin{array}{l}0.198 \\
0.100 \\
0.161 \\
0.450 \\
0.200\end{array}$ & $\begin{array}{l}36 \cdot 3 \\
36 \cdot 3 \\
36 \cdot 2 \\
36: 2 \\
36.2\end{array}$ & $\begin{array}{l}57.4 \\
57.4 \\
57.7 \\
57: 9 \\
57.9\end{array}$ & $\begin{array}{r}1379 \\
1201 \\
725 \\
402 \\
402\end{array}$ & $\begin{array}{l}0.99 \\
0.99\end{array}$ & & $\begin{array}{l}1: 20 \\
1.23 \\
1.19 \\
1.51 \\
1.27\end{array}$ & $\begin{array}{l}1.12 \\
1.07 \\
1.05 \\
1.26 \\
1.08\end{array}$ \\
\hline $\begin{array}{l}\text { SCTDR-S - } 60.20 \\
\text { SCTDR-H - 60.20 } \\
\text { SCTDR-L-60..20 }\end{array}$ & $\begin{array}{ll}D & R \\
\text { D } & \text { " } \\
& " 1\end{array}$ & $\begin{array}{l}0.199 \\
0.200 \\
0.200\end{array}$ & & $\begin{array}{l}58.1 \\
58.1 \\
57.9\end{array}$ & $\begin{array}{r}1379 \\
725 \\
402\end{array}$ & & & & $\begin{array}{l}1.17 \\
1.13 \\
1.17\end{array}$ \\
\hline $\begin{array}{l}\text { LCTDI - S - 60.20 } \\
\text { LCTDI -S -60.10 } \\
\text { LCTDI - L-60.35 } \\
\text { LCTDI - - } 60.25\end{array}$ & $\begin{array}{ll}D & I \\
n & " 1 \\
\text { " } & " 1 \\
\text { " } & " 1\end{array}$ & $\begin{array}{l}0.203 \\
0.101 \\
0.350 \\
0.250\end{array}$ & $\begin{array}{l}72.6 \\
72.5 \\
72.6 \\
72.6\end{array}$ & $\begin{array}{l}58.6 \\
58.7 \\
58.6 \\
58.6\end{array}$ & $\begin{array}{r}1155 \\
1155 \\
450 \\
450\end{array}$ & $\begin{array}{l}2 . \\
1 . \\
1 \text { : }\end{array}$ & & $\begin{array}{l}1.13 \\
1.19 \\
1.44 \\
1.17\end{array}$ & $\begin{array}{l}1.05 \\
1.04 \\
1.25 \\
1.02\end{array}$ \\
\hline $\begin{array}{l}\text { LCTDC-S - 60.20 } \\
\text { LCTDC }-5-60.10 \\
\text { LCTDC-L-60.35 } \\
\text { LCTDC-L-60.25 }\end{array}$ & $\begin{array}{ll}\text { D } & \text { C } \\
\text { "n } & n \\
\text { " } & " \text { " }\end{array}$ & $\begin{array}{l}0.203 \\
0.101 \\
0.350 \\
0.250\end{array}$ & $\begin{array}{l}72.5 \\
72.5 \\
72.5 \\
72.7\end{array}$ & $\begin{array}{l}58.7 \\
58.6 \\
58.6 \\
58.6\end{array}$ & $\begin{array}{r}1155 \\
1155 \\
450 \\
450\end{array}$ & $\begin{array}{l}2.87 \\
2.87 \\
1.12 \\
1.12\end{array}$ & & $\begin{array}{l}1.17 \\
1.23 \\
1.41 \\
1.25\end{array}$ & $\begin{array}{l}1.08 \\
1.07 \\
1.23 \\
1.09\end{array}$ \\
\hline LCTSC-S-60.10 & $\mathrm{s}$ & 0.101 & 72.6 & 58.6 & 1155 & 2.87 & 402 & 1.12 & 0.97 \\
\hline
\end{tabular}

表 4.B 試験体と実験結果 $(\phi 139.8 \times 2.8$ の試験体 $)$

\begin{tabular}{|c|c|c|c|c|c|c|c|c|c|}
\hline Specimen & Loading & $\mathrm{N} / \mathrm{N}_{\mathrm{u}}$ & $\mathrm{L}_{\mathrm{c}}$ & $D / t$ & $\sigma_{\mathrm{c}}$ & $\rho$ & $\mathrm{M}_{\mathrm{m}}$ & $\mathrm{M}_{\mathrm{m}} / \mathrm{M}_{\mathrm{u}}$ & $\mathbf{M}_{\mathbf{m}} / \mathbf{M}_{\mathrm{ue}}$ \\
\hline 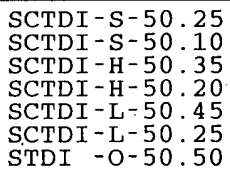 & $\begin{array}{l}\mathrm{D} \\
\text { " } \\
" 1 \\
" 1 \\
" 1 \\
" 1 \\
" 1 \\
" 1\end{array}$ & $\begin{array}{l}0.227 \\
0.117 \\
0.370 \\
0.191 \\
0.449 \\
0.250 \\
0.485\end{array}$ & $\begin{array}{l}36.2 \\
36 \cdot 3 \\
36 \cdot 3 \\
36.2 \\
36 \cdot 3 \\
36 \cdot 2 \\
36.2\end{array}$ & $\begin{array}{l}50.4 \\
50.4 \\
50.4 \\
50.4 \\
50.4 \\
50.5 \\
50.5\end{array}$ & $\begin{array}{r}1194 \\
1194 \\
585 \\
585 \\
302 \\
359\end{array}$ & $\begin{array}{l}3.14 \\
3.14 \\
1.54 \\
1.54 \\
0.79 \\
0.94 \\
0.00\end{array}$ & $\begin{array}{l}524 \\
471 \\
479 \\
442 \\
475 \\
389 \\
189\end{array}$ & $\begin{array}{r}1.32 \\
1.39 \\
1.61 \\
1.51 \\
1.94 \\
1.52 \\
1.87\end{array}$ & $\begin{array}{l}1.19 \\
1.17 \\
1.38 \\
1.26 \\
1.43 \\
1.22 \\
1.10\end{array}$ \\
\hline 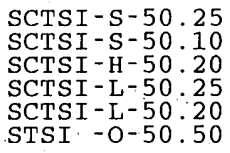 & $\begin{array}{ll}\mathrm{S} & \mathrm{I} \\
" & " 1 \\
" & " 1 \\
" & " 1 \\
" & \end{array}$ & $\begin{array}{l}0.227 \\
0.117 \\
0.191 \\
0.250 . \\
0.193 \\
0.485\end{array}$ & $\begin{array}{l}36 \cdot 2 \\
36 \cdot 2 \\
36 \cdot 2 \\
36 \cdot 2 \\
36 \cdot 2 \\
36 \cdot 2\end{array}$ & $\begin{array}{l}50.4 \\
50.4 \\
50.4 \\
50.5 \\
50.4 \\
50.5\end{array}$ & $\begin{array}{r}1194 \\
1194 \\
585 \\
359 \\
359 \\
-\end{array}$ & $\begin{array}{l}3 \cdot 14 \\
3 \cdot 14 \\
1 \cdot 54 \\
0.94 \\
0.94 \\
0.00\end{array}$ & $\begin{array}{l}485 \\
426 \\
398 \\
359 \\
353 \\
162\end{array}$ & $\begin{array}{l}1.22 \\
1.26 \\
1.36 \\
1: 40 \\
1.39 \\
1.61\end{array}$ & $\begin{array}{l}1.10 \\
1 \cdot 06 \\
1.13 \\
1.12 \\
1.11 \\
0.95\end{array}$ \\
\hline $\begin{array}{l}\text { SCTDC-S-50.25 } \\
\text { SCTDC-S-50.10 } \\
\text { SCTDC-H-50.25 } \\
\text { SCTDC-L-50..45 } \\
\text { SCTDC-L-50.25 }\end{array}$ & 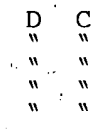 & $\begin{array}{l}0.250 \\
0.100 \\
0.250 \\
0.449 \\
0.249\end{array}$ & $\begin{array}{l}36 \cdot 2 \\
36 \cdot 3 \\
36 \cdot 3 \\
36 \cdot 2 \\
36 \cdot 3\end{array}$ & $\begin{array}{l}50.5 \\
50.5 \\
50.4 \\
50.4 \\
50.4\end{array}$ & $\begin{array}{r}1201 \\
1201 \\
724 \\
302 \\
302\end{array}$ & $\begin{array}{l}3.19 \\
3.16 \\
1.90 \\
0.79 \\
0.79\end{array}$ & $\begin{array}{l}575 \\
480 \\
485 \\
409 \\
381\end{array}$ & $\begin{array}{l}1.41 \\
1.46 \\
1.49 \\
1.91 \\
1.56\end{array}$ & $\begin{array}{l}1.29 \\
1.21 \\
1.29 \\
1.41 \\
1.23\end{array}$ \\
\hline SCTSC-S-50.25 & $\mathrm{S}$ & 0.250 & 36.3 & 50.5 & 1201 & 3.16 & 514 & 1.26 & 1.15 \\
\hline $\begin{array}{l}\text { LCTDI - S-50.20 } \\
\text { LCTDI - S-50.1 } \\
\text { LCTDI - L }-50.25\end{array}$ & · & $\begin{array}{l}0.200 \\
0.100 \\
0.205\end{array}$ & $\begin{array}{l}72.4 \\
72.5 \\
72.6\end{array}$ & $\begin{array}{l}50.5 \\
50.4 \\
50.5\end{array}$ & $\begin{array}{r}1155 \\
1155 \\
429\end{array}$ & $\begin{array}{l}3.04 \\
3.03 \\
1.13\end{array}$ & $\begin{array}{l}443 \\
388 \\
337\end{array}$ & $\begin{array}{l}1.17 \\
1.20 \\
1.26\end{array}$ & $\begin{array}{l}1.03 \\
0.99 \\
1.02\end{array}$ \\
\hline $\begin{array}{l}\text { LCTDC-S }-50.20 \\
\text { LCTDC-S }-50.10 \\
\text { LCTDC-L-50.25 }\end{array}$ & $\begin{array}{ll}\mathrm{D} & \mathrm{C} \\
" & " 1 \\
" & "\end{array}$ & $\begin{array}{l}0.200 \\
0.100 \\
0.250\end{array}$ & $\begin{array}{l}72.8 \\
72.6 \\
72.5\end{array}$ & $\begin{array}{l}50.5 \\
50.5 \\
50.5\end{array}$ & $\begin{array}{r}1146 \\
1146 \\
429\end{array}$ & $\begin{array}{l}3.01 \\
3.01 \\
1.13\end{array}$ & $\begin{array}{l}445 \\
419 \\
350\end{array}$ & $\begin{array}{l}1.18 \\
1.30 \\
1.29\end{array}$ & $\begin{array}{l}1.04 \\
1.07 \\
1.06\end{array}$ \\
\hline
\end{tabular}


表 4.C 試験体と実験結果 ( $\phi 101.6 \times 3.2$ の試験体)

\begin{tabular}{|c|c|c|c|c|c|c|c|c|c|}
\hline Specimen & Loading & $\mathrm{N} / \mathrm{N}_{\mathrm{u}}$ & $\mathrm{L}_{\mathrm{c}}$ & $D / t$ & $\sigma_{c}$ & $\rho$ & $\mathbf{M}_{\mathrm{m}}$ & $\mathrm{M}_{\mathrm{m}} / \mathrm{M}_{\mathrm{u}}$ & $\mathrm{M}_{\mathrm{m}} / \mathrm{M}_{\mathrm{ue}}$ \\
\hline $\begin{array}{l}\text { SCTDI-S-30.25 } \\
\text { SCTDI -S - 30.10 } \\
\text { SCTDI-H-30.20 } \\
\text { SCTDI-L-30.25 }\end{array}$ & $\begin{array}{ll}\mathrm{D} & \mathrm{I} \\
" & " 1 \\
" & "\end{array}$ & $\begin{array}{l}0.247 \\
0.108 \\
0.196 \\
0.264\end{array}$ & $\begin{array}{l}25.0 \\
24.9 \\
25.0 \\
24.9\end{array}$ & $\begin{array}{l}34.2 \\
34.2 \\
34.0 \\
34.0\end{array}$ & $\begin{array}{r}1383 \\
1308 \\
446 \\
180\end{array}$ & $\begin{array}{l}2.33 \\
2.20 \\
0.75 \\
0.30\end{array}$ & $\begin{array}{l}301 \\
251 \\
221 \\
221\end{array}$ & $\begin{array}{l}1.46 \\
1.43 \\
1.52 \\
1.84\end{array}$ & $\begin{array}{l}1.34 \\
1.23 \\
1.26 \\
1.39\end{array}$ \\
\hline $\begin{array}{l}\text { SCTSI-S-30.25 } \\
\text { SCTSI-S-30.10 } \\
\text { SCTSI-H-30.20 }\end{array}$ & $\begin{array}{ll}\text { S } & \text { I } \\
" 1 & " 1\end{array}$ & $\begin{array}{l}0.248 \\
0.108 \\
0.197\end{array}$ & $\begin{array}{l}25.0 \\
24.9 \\
25.0\end{array}$ & $\begin{array}{l}34.2 \\
34.2 \\
34.0\end{array}$ & $\begin{array}{r}1383 \\
1308 \\
446\end{array}$ & $\begin{array}{l}2.33 \\
2.20 \\
0.75\end{array}$ & $\begin{array}{l}249 \\
234 \\
221\end{array}$ & $\begin{array}{l}1.21 \\
1.33 \\
1.53\end{array}$ & $\begin{array}{l}1.11 \\
1.14 \\
1.27\end{array}$ \\
\hline $\begin{array}{l}\text { STDI }-0-30.35 \\
\text { STDR }-0-30.35 \\
\text { STSI }-0-30.35 \\
\text { STSR }-0-30.35\end{array}$ & $\begin{array}{ll}D & I \\
D & R \\
S & I \\
S & R\end{array}$ & $\begin{array}{l}0.346 \\
0.345 \\
0.345 \\
0.346\end{array}$ & $\begin{array}{l}24 \cdot 9 \\
24 \cdot 9 \\
24 \cdot 9 \\
24.9\end{array}$ & $\begin{array}{l}34 \cdot 2 \\
34 \cdot 3 \\
34 \cdot 2 \\
34.2\end{array}$ & $\begin{array}{l}- \\
-\end{array}$ & $\begin{array}{l}0.00 \\
0.00 \\
0.00 \\
0.00\end{array}$ & $\begin{array}{l}139 \\
133 \\
119 \\
123\end{array}$ & $\begin{array}{l}1.58 \\
1.49 \\
1.34 \\
1.38\end{array}$ & $\begin{array}{l}1.21 \\
1.15 \\
1.03 \\
1.07\end{array}$ \\
\hline LCTDI -S -30.25 & $\mathrm{D}$ & 0.254 & 50.2 & 34.2 & 1336 & 2.25 & 276 & 1.36 & 1.25 \\
\hline $\begin{array}{ll}\text { LTDI } & -0-30.35 \\
\text { LTDR } & -0-30.35 \\
\text { LTSI } & -0-30.35 \\
\text { LTSR } & -0-30.35\end{array}$ & $\begin{array}{ll}D & I \\
D & R \\
S & I \\
S & R\end{array}$ & $\begin{array}{l}0.346 \\
0.346 \\
0.345 \\
0.345\end{array}$ & $\begin{array}{l}50.1 \\
50.0 \\
50.0 \\
50.1\end{array}$ & $\begin{array}{l}34 \cdot 2 \\
34 \cdot 2 \\
34 \cdot 3 \\
34 \cdot 3\end{array}$ & - & $\begin{array}{l}0.00 \\
0.00 \\
0.00 \\
0.00\end{array}$ & $\begin{array}{l}123 \\
130 \\
111 \\
124\end{array}$ & $\begin{array}{l}1.39 \\
1.47 \\
1.25 \\
1.39\end{array}$ & $\begin{array}{l}1.07 \\
1.13 \\
0.97 \\
1.07\end{array}$ \\
\hline
\end{tabular}

試験体名の表示

$\frac{S}{1} \frac{C T}{2} \frac{D}{3} \frac{I}{4}-\frac{S}{5}-\frac{60}{6} \cdot \frac{20}{7}$
1: 柱長さ ( $\left.S: L_{c} J D=2.5, L: L_{c} D=5.0\right)$

2: 鋼管 $(T)$, コンクリート充填鋼管 $(C T)$

3: 静載荷 $(S)$, 動載荷 $(D)$

4: 時刻歴変位波形

$I$ : 漸増振幅交番繰り返し変位,

$C$ : 定振幅交番繰り返し変位,

$R:$ 不規則変位

5: コンクリート圧縮強度 $(S, H, L)$

6: 鋼管径厚比 $(D / t=30,50,60)$

7: 軸力比 $\left(N / N_{u}, N_{u}=\sigma_{c} A_{c}+\sigma_{u} A_{s}\right)$

$$
\begin{array}{ll}
L_{c} & : \text { 柱長 }(\mathrm{cm}) \\
D / t & : \text { 鋼管径厚比 } \\
\sigma_{\mathrm{c}} & : \text { コンクリート压樎強度 }\left(\mathrm{kg} f\left(\mathrm{~cm}^{2}\right)\right. \\
\rho & : \text { コンクリート鋼管強度比 }\left(=\sigma_{\mathrm{c}} A_{c} / \sigma_{\mathrm{u}} A_{s}\right) \\
M_{m} & : \text { 最大曲げ荷重 }(t f . c m) \\
M_{u} & : \text { 一般化累加強度式の終局曲げ耐力 } \\
M_{u e} & : \text { (7) 式の終局曲げ耐力 }
\end{array}
$$

謝辞 本研究は平成 8-10 年度文部省科学研究費 (基盤研究 (B) 研究代表者 最相元雄) による研究の一部である。又、試験体の製作に際しては住友金属 工業株式会社の協力を得た。記して感謝致します。

\section{参考文献}

1) 岡本達雄，前野敏元，益尾㵖，西澤英和，金多 潔：高強度遠心成形鍽 管コンクリート柱の圧縮酎力に関する実験的研究, 日本建築学会構造系論文 集, 第 469 号, 1995.3 .

2) 宮木聡, 松井千秋, 畑戸龍夫, 今村輝武, 吉野茂, 中克己 : 遠心成形コンク リート立填銅管柱の耐力・変形性能, 日本建築学会構造系論文集, 第 500 号, 1997.10.

3) 藤本利昭, 向井昭義, 西山功, 稲井栄一, 甲斐誠, 時野谷浩良, 馬場武志, 福元敏之, 森浩二, 崎野健治, 森野捷輔：高強度材料を用いたコンクリート立 てん鍓管柱の曲げせん断性状, 日本建築学会構造系論文集，第 509 号, 1998.7.

4) 越智敏夫, 辻文三, 中島正愛, 楊柳, 遠藤創: 水平力を受ける内形コンク リート充填銅管柱の復元力特性, 日本建築学会大会学術講演梗概集, 1992.8 .

5) 吉野茂, 畑戸龍夫 , 多賀章, 今村輝武, 渡辺朋之, 宮木聘: 銅管コンクリー 卜構造の開発 その 6, 日本建築学会大会学術講演梗概集, 1993.9 .

6) 佐藤孝典，金本清臣：充填銅管コンクリート構造における銅とコンクリ 一トの分担力抽出のための変形経路再現実験, 日本建築学会構造系論文集, 第 468 号, 1995.2.

7) 加藤勉：曲げと圧緶をうけるコンクリート充填鋼管柱の耐力, 変形能力 (コンクリート充填銅管柱の耐力, 変形能力の研究, II ) , 日本建築学会構造 系論文集, 第 477 号, 1995.11.

8) 佐藤孝典: 充填鋼管コンクリート柱の部材酎力の提案, 日本建築学会大会 学術講演梗概集, 1997.9 .

9) 日本建築学会: コンクリート充填銅管構造設計施工指針, 1997.10.

10)崎野健治,蛈川利彦: ハイブリッド構造に関する日米共同構造実験研究 (CFT-35) 円形 CFT 柱の終局曲げ酎力算定式の提案, 日本建築学会大会学術講 演梗概集，1998.9.

11) 富井政英，吉村浩二，森下陽一，吹原正晃：中心压縮を受けるコンクリ 一下充填鋼管短柱に関する研究 (その 1-2), 日本建築学会大会学術講演梗概

集, 1977.10.

12）越智敏夫, 过文三, 中島正愛, 楻楖, 森田晋治：コンクリート充填鋼管柱 の曲げ座屈酎力 (その 1-2), 日本建築学会大会学術講演梗概集, 1991.9 .

13) 北田俊行, 吉田康樹, 中井博 : コンクリートを充填した鋼管短柱の弾塑 性举動に関する基礎的研究,構造工学論文集, Vol.34A, 1988.3.

14）山口育雄, 菅野俊介, 長嶋俊雄, 平出亨, 沢田博 : 立てん型銅管コンクリ

一ト短柱の中心圧縮性状 その 1 , 日本建築学会大会学術講演梗概集, 1988.10.
15) 上遠野明夫, 山口種美 : 夼填型銅管コンクリート柱に関する研究 その 2 , 日本建築学会大会学術講演梗概集, 1989.10 .

16) 田中清他: 合成短柱の力学性状に関する研究 その 1 , 日本建築学会大会 学術講演梗概集, 1989.10 .

17) 渡辺朋之, 多賀章, 岩岡信一: 鋼管コンクリート構造の開発 その 4, 日本 建築学会大会学術講演梗概集, 1993.9 .

18) 時野谷浩良, 田中義成, 福本昇, 村田義行, 藤本利明, 向井昭義: ハイフ リッド構造に関する日米共同構造実験研究 (CFT-3) コンクリート充てん銅管 柱の軸圧縮 その 3, 日本建筑学会大会学術講演梗概集, 1995.8 .

19) 馬場武志, 藤本利昭, 向井昭義 , 西山功, ハイブリッド構造に関する日米 共同構造実験研究 (CFT-10), コンクリート充てん銅管柱の曲げせん断性状 そ の2, 日本建筑学会大会学術講演梗概集, 1996.9.

20) 前野敏元他, $160 \mathrm{~N} / \mathrm{mm}^{2}$ 級のコンクリートを用いたコンクリート立填銅 管柱の中心圧縮実験, 日本建築学会大会学術講演梗概集, 1996.9.

21) 植坂武史, 吉川祐三, 斉藤啓一, 古海賢二, 小浜洋輔, 清水孝悦: 冷間成 形円形鋼管と高強度コンクリートを用いた立填型鋼管コンクリート構造の実 験的研究 その 1 , 日本建築学会大会学術講演梗概集, 1996.9 .

22）小松慎二, 蜞川利彦, 崎野健治, 石出一郎 : コンクリート克填円形錭管柱 の弾塑性性状に関する研究 その 1 , 日本建築学会大会学術講演梗概集, 1996.9.

23）大塚貫弘，鈴木敏郎，元結正次郎，太田秀彦: 軸圧縮を受けるコンクリー 卜充填円形銅管短柱の力学的特性に関する研究 その 1-3, 日本建築学会大会学 術講演梗概集, 1997.9 .

24）佐藤孝典：円形断面の充填銅管コンクリート構造におけるコンファイン ド効果のメカニズムとそのモデル化, 日本建筑学会構造系論文集, 第 452 号, 1993.10 .

25)䗷川利彦, 小松慎二, 崎野健治: 中心圧綟力を受けるコンクリート充填 円形鋼管短柱におりる拘束効果, 日本建築学会構造系論文集, 第 506 号, 1998. 4.

26) M.Saisho and K.Mitsunari: Dynamic Restoring Force Characteristics of Steel Tube Filled with Super-High Strength Concrete, 10WCEE, Vol.VI, 1992.8.

27) M. Saisho and K. Mitsunari: Experimental Study on Dynamic Behavior of Steel Tube Filled with Super-High Strength Concrete, 4-ASCCS, Steel Concrete Composite Structures, 1994.6.

28) K.Mitsunari and M.Saisho: Ultimate Strength and Plastic Deformation Capacity of CFT Beam-Column Subjected to Dynamic Load, 11WCEE, 1996.6.

29) 最相元雄, 光成和昭：超高強度コンクリート充填銅管せん断曲げ柱の終 局挙動に関する実験的研究, 日本建築学会構造系論文集, 第 520 号, 1999.6.

30) 最相元雄, 岡部猛, 光成和昭: 超高強度コンクリート充填鋼管短柱の拘 束効果と終局耐力に関する実験的研究，構造工学論文集，Vol.42B, 1996.3. 